\title{
Ecstatic Hymns: The Hymn's Role in Encountering Mystery in Liturgical Worship
}

\author{
Megan Heeder \\ Boston College School of Theology and Ministry (Brighton, MA)
}

\begin{abstract}
The Mass's music enables us to encounter God by being drawn out of ourselves by beauty. Thus, hymns form us ecstatically by engaging the intellectual, physical, and spiritual elements of our human nature to better know and love God as Mystery and Beauty Engaging the whole human person, singing enables us to offer God all of ourselves and so encounter God as Mystery. Drawing on the work of Hans Urs von Balthasar writes, this paper will reflect on how the beauty of song invites us into the Mystery of Beauty: God. Singing a hymn of praise is a transformative experience of beauty, which draws us out of ourselves, placing us in a posture in which we can encounter and be formed by God, and so more fully be able to encounter God, others, and ourselves.
\end{abstract}

\section{Text}

\section{Introduction}

Within the formative ecstatic ${ }^{1}$ reality of the Mass, music - particularly the hymn - is central to our understanding of God and the act of worship. The gift of music itself connects us to God as God's gift; the United States Conference of Catholic Bishops' (USCCB) Sing to the Lord reminds us that God is the giver of song and that music is a means by which God leads us to higher things. Thus, it is fitting that communal hymns of praise find their place in the Mass as a means through which God's sacramental presence is communicated. ${ }^{2}$ In his Sermo 336, Augustine also writes that "Singing is for the one who loves." 3 Song, as God's gift, is a mark

\footnotetext{
${ }^{1}$ Lumen et Vita's conference is based on an understanding of the original meaning of ecstasy, that is "to stand outside," in reference to instances of being drawn outside the self in an encounter with the Divine, which makes possible a "fuller encounter with another" (Lumen et Vita Spring 2018 "Love and Ecstasy: Emptying the Self, Encountering the Other" conference description). This is the understanding of ecstasy operative in the body of this paper.

${ }^{2}$ United States Conference of Catholic Bishops (USCCB), Sing to the Lord: Music in Divine Worship (Washington, D.C.: United States Conference of Catholic Bishops, 2008), 8.

${ }^{3}$ St. Augustine, Sermo 336, 1 (PL 1844-1855, 38, 1472); USCCB, Sing to the Lord, 8.
} 


\section{HEEDER: ECSTATIC HYMNS}

of God's love for us; raising our voices in song, returning to God the very gift God gave to us, is an act of love unto God. ${ }^{4}$

Singing engages the mind, body, and soul as an embodied, ecstatic act of love and worship. In other words, singing hymns is a means of encountering Godpraying - in and through the whole human person via music and community, which become formative in love. Hymns form us ecstatically through mystery and beauty by engaging the intellectual, physical, and spiritual elements of our human nature to better know and love God as Mystery and Beauty.

\section{Hymns' Ecstatic Nature: Drawing Out the Fullness of Our Humanity}

Hymns are, by nature, ecstatic. Hymns are written to convey truths about God and offer both our praise and our very selves to God, communicated through many forms (e.g., praise, description, apophatic theology, or memories from the annals of salvation history). Thus, well-written, theologically correct hymns are means of theological education; they teach us about God and faith, increasing our knowledge via an encounter not only with the truths of faith, but with God so that we might grow in love. We may realize this truth of God's presence and love in a way that becomes deeply interior to and united with our embodied experience through the ritual of pronouncing them aloud together in song (which is not dissimilar to the recitation of the Creed which contains the fundamental truths of our faith). However, hymns are not only means of teaching "about" truth, but encountering the ultimate Truth (God); we proclaim these truths in communion with others in song, marking the truths as our own and as belonging to the community. This is epitomized in hymnody, which has become a cherished part of the Catholic tradition. We are drawn out of ourselves as we grow in knowledge and make God's truths our own by singing and praying hymns.

Hymns are written to be sung prayerfully. Singing is an action which naturally engages both our bodies and spirit. By engaging our minds and bodies, uniting them in prayer and communication with God, the wholeness of our humanitymind, body, and spirit — is engaged in worship as we are drawn beyond the "self." The "work" of singing (i.e., reading music, listening to others, forming words and notes to the best of our ability) is itself a sacrifice, an incarnate offering to God. When we offer all that we are to God in the act of sacrifice that is song, the fullness of our humanity can be shaped by God.

Particularly in the context of the Mass, hymns unite us in community by drawing us outside of ourselves. The voices of the congregation rise and fall in harmony as they give life to hymns' notes and text. Often, it is easier to forget the faults of the neighbor beside us as we sing together, united in word and music-

\footnotetext{
${ }^{4}$ USCCB, Sing to the Lord: Music in Divine Worship, 8.
} 


\section{HEEDER: ECSTATIC HYMNS}

and, if instead it becomes easier to recognize our neighbors' faults in song, the invitation to charity extended via this experience of community resonates all the louder. In the context of the whole ecclesial community, giving voice to the hymns (or elements of the acclamations for the Eucharistic rite, in which we are invited to raise our voices in song "with all the angels and saints") unites us to the communion of saints, who eternally sing God's praise. It is worth noting that many of our most treasured hymns use the text of saints' own writings, prayers, or were even written or sung by the saints themselves! $!^{5}$

\section{Hymns' Pedagogy: How We Are Formed and Drawn Out of Ourselves in Love}

It is clear that hymns' text, their nature as music realized by the act of singing, and their place in communal worship all reveal the ecstatic nature of hymnody. A deeper plumbing of hymns' pedagogy, or how they form us ecstatically, reveals some of the ways hymns' mystery and beauty facilitate an encounter with God.

1. Textually, many hymns illustrate God and theological truths with great beauty. Hymns, like the psalms, also express a range of human emotions, from the rawest of grief to the most exultant joy (sometimes within the same hymn). The text engages reason and the art of prose in order to help us know God, theological truths, and express the experience of being in relationship with the divine and others. All three aspects are ecstatic and aid our understanding of who God is, how God meets us in our humanity, and how to better live the life of faith.

2. Musicologically, music communicates via note patterns and rhythms, key choices, dynamics, musical phrasing, and other musical elements. Tracing the mysterious collaboration of ascending and descending lines; phrasing of the text and melody; dynamic increases or decreases and many other elements enrich what the text communicates by both engaging the body in expressing these truths through the voice and by creating an artistic expression through which one can both hear and enter into the truth of what is being conveyed.

3. The experience of singing with others either as a member of the congregation or the choir is also formative. As members of the community of the Body of Christ, we are called to love our neighbor as we love ourselves-learning (or singing) music with others (which includes learning to listen and blend with the group; repeating portions of songs by which one might not be challenged, but with which other choral members struggle; being responsible for a mistake that is not only heard, but named by others in the choral group so that it can be corrected in order

5 Examples include St. Thomas Aquinas' "Pange Lingua," or "O Salutaris," St. Ambrose's "Te Deum," or St. Francis' "Prayer of St. Francis" (better known as "Make Me a Channel of Your Peace") 


\section{HEEDER: ECSTATIC HYMNS}

to strengthen the choral body's performance) are a few ways in which singing with others exercises and forms our ability to love and be with others in community. Music ministers and congregation, together raising their voices in praise, form one choir offering prayer and song to God as they are formed by the experience of communal singing.

4. Music ministers sing with (not "for") the congregation, but having spent time growing in prayerful knowledge of the text, music, and choral singing of the hymn, music ministers establish a relationship with the hymn, much like one might with a beloved prayer, poem, or other piece of art. The depth of their relationship with the hymn enables the music minister to deeply understand and therefore communicate the hymn's truth and depth through their body language, facial expression, and the richness of their choral singing. Through this sacrifice of their time in both private and communal rehearsal and the energy necessary for good singing and musical communication, music ministers uniquely communicate the hymn's beauty and invite the congregation into a deeper understanding of and, perhaps even an encounter with, the divine through their singing.

5. There is also great mystery inherent to how hymns function in the liturgy; no amount of analysis can reduce the shimmer of mystery and beauty that adorns a well-sung hymn to a mere combination of elements. The rush of human emotion, awe, or surprise of tears from a beautifully sung hymn in the context of liturgy point to an "other," inexplicable element-both in the hymn and in ourselves. Mystery is encountered, at work in, and conveyed through beautiful music, and beauty's mystery awakens part of our humanity which responds mysteriously to beauty in a way that we rarely understand, pointing us to something simultaneously inside, yet beyond the self, beyond the capacity of rational understanding. Perhaps we can have an ecstatic encounter with the Other within the ineffable mystery of our selves, made possible by the hymn's beauty and mystery.

The hymn's text, music, communal context, and liturgical performance engage all components of our humanity, enabling us to offer God all of ourselves as we pray through song in Mass. We are simultaneously drawn out of ourselves to encounter those whose voices soar with us in song and to embrace and adore our God. The mystery and beauty of the hymn, defying human analytical efforts, form us through encounter: the incarnation of song through our voices and beings; the engagement of our souls as we not only sing but pray the hymns; the engagement of our minds as we understand the text, the music, and the truth both convey together; the communal nature of the practice and expression of song; and engagement through listening to the beauty and mystery we have created and offer to God as one Body in Christ. 


\section{HEEDER: ECSTATIC HYMNS}

\section{Beauty and Mystery: Encounter and Transformation through the Hymn}

The beauty of song, engaging all that is human in us, invites us through encounter to know God as Beauty and Mystery. As Hans Urs von Balthasar writes, beauty educates us in mystery ecstatically, drawing us outside of ourselves towards the Mystery of Beauty that is God. In von Balthasar's analysis of beauty in The Glory of the Lord, beauty is a union of two elements: species and lumen. Species refers to the tangible form of the art accessible to the senses while the "splendor" which emanates from the form, enchanting and drawing the perceiver inward, is the lumen. When one encounters beauty, von Balthasar says that one encounters "the real presence of the depths, of the whole reality, and ... a real pointing beyond itself to those depths." $"$ Thus, as the lumen emanates from the species, the viewer is drawn into the mystery of beauty, beyond the self and beyond time or place to encounter the beautiful thing in itself. To enter into the form's beauty, one must renounce or forget one's self in a sacrificial act in order to authentically encounter and enter into the beauty of the other; a posture of receptivity is central to being able to encounter beauty and receive it openly, with a heart open to transformation through beauty's mysteriousness, resisting the all-too-human desire to warp, shrink, or manipulate it.

Mystery is at work in this encounter as well, especially through beauty's lumen. Just as the visible form " "points' to an invisible, unfathomable mystery," form is simultaneously "the apparition of this mystery, and reveals it while, naturally, at the same time protecting and veiling it."7 The mechanics of beauty cannot be fully explained, though its species can be explored, and its mystery is best respected through a posture of humility and awe. Encountering beauty necessitates a posture which accepts the unknowing of mystery in opposition to the possibility of complete understanding; this posture echoes that which the mystery of God's Trinitarian nature calls forth. Mystery is at work through hymns' species and lumen, through hymns' nature as prayer and art.

Transformation comes not only through the hymn's ability to draw the self out into the mystery of its beauty, making possible an encounter with the Other, but also because of the posture needed to truly sing and pray a hymn. Song is both incarnational and divine, beautiful and mysterious, touching and calling upon all of our human nature as we sing praise; as such, the hymn facilitates an encounter with the divine which is a graced opportunity to assume a posture in which the one who prays the hymns can receive and be formed by the Other in love. Thus, when we

${ }^{6}$ Hans Urs von Balthasar, The Glory of the Lord: A Theological Aesthetics, Volume 1: Seeing the Form, trans. Erasmo Leiva-Merikakis (San Francisco: Ignatius Press, 1982), 118-119.

${ }^{7}$ von Balthasar, Seeing the Form, 151. 


\section{HEEDER: ECSTATIC HYMNS}

sing hymns in a posture of humble, loving receptivity to Mystery and Beauty, offering the self openly with full heart and voice, we are drawn out of ourselves to encounter and love God who forms us to make a return of that love to our neighbor and back to our God. Then, once again, with the angels and saints whose ranks we aspire to join, we are invited to sing ecstatic hymns of praise to our God. ${ }^{8}$

\section{Bibliography}

Balthasar, Hans Urs von. The Glory of the Lord: A Theological Aesthetics, Volume 1: Seeing the Form. Translated by Erasmo Leiva-Merikakis. San Francisco: Ignatius Press, 1982.

United States Conference of Catholic Bishops. Sing to the Lord: Music in Divine Worship. Washington, D.C.: United States Conference of Catholic Bishops, 2008 .

\section{Appendix: Case Study9}

To conclude, I would like to offer a brief exegesis of a beloved hymn to serve as a case study of how hymnal theological aesthetics function ecstatically with mystery and beauty as laid out in this paper. Please direct your attention to the first verse of "For the Beauty of the Earth" as I offer a few brief remarks on each of the five areas addressed a few moments ago.

\section{Text}

a. The hymn's first verse contains parallel structures until the stanza before the refrain where the break in form attracts our attention. This break in form draws our attention to the hymn's object, the Lord to whom we are giving praise (by raising "our hymn of grateful praise") for the Earth's beauty, the skies' glory, and love which surrounds us "from our birth." Love that abides over and around us, vertically and horizontally, from the Lord as well as the friends and family with whom God has graced us, to love us with - and in whom we encounter-God's own love (which is the topic of the verse's final two stanzas). Each line of the hymn's prose points us to the

\footnotetext{
${ }^{8}$ For a case study utilizing the aforementioned principles, see the Appendix below.

${ }^{9}$ This case study was presented to conclude the oral delivery of this paper at Lumen et Vita's spring conference, "Love and Ecstasy: Emptying the Self, Encountering the Other," on February $3,2018$.
} 


\section{HEEDER: ECSTATIC HYMNS}

refrain (emphasized by the colon at the end of each verse), to the Lord to whom we praise for what each verse describes.

2. Music

a. Two stanzas of music repeat with the four lines of text; the pattern A-B/A-B/refrain is used in the hymn.

b. Rhythms are straightforward, with each phrase's final note (a half note) receiving the most time. The refrain is the only place where non-tied eighth note rhythms are used, creating phrases that are comparatively more legato and connected, particularly in the manner in which they build to the phrase "to you we raise"- emphasizing, appropriately, the Lord to whom this hymn of praise is directed.

3. The fullness of the message

a. The A-B/A-B/ refrain pattern mirrors the first verse of the hymn's message, with the Lord as the source of all of earth's good things (beauty, glorious skies, and love that surrounds us). The hymn's highest note (and usually therefore the loudest, as volume naturally increases with ascending tones) occurs on - and calls attention tothe word "you" (addressing the Lord as the one to whom our praises are being offered). "You" also commands the only non-tied eighth note and an ascending third interval or jump, which further attracts our attention to the fact that it is to the "Lord of all" to whom we raise our hymn of grateful praise.

4. Community

a. Next, I am going to invite us to sing this hymn together, as one "choir." As we raise our voices to offer this prayer together, I invite you to be attentive to a few elements of choral singing:

i. Pay attention to the words and the emotion they convey and evoke in you. What would you like an audience to pick up on in this verse via your verbal and facial communication?

ii. Listen to those voices around you. You should neither hide behind nor overpower the voices surrounding you. This experience of prayer is about unity and voicing praise with others versus being a concert-performance.

iii. Please join in with full heart and voice, challenging yourself in this mode of prayer as you feel comfortable.

5. "Other": Reflection and questions on the element of mystery

a. Be attentive to what the act of singing, listening, and watching what/how others communicate moves in you.

b. How are you growing in knowledge, appreciation, or gratitude of the Other as you are drawn beyond yourself (internally or externally) 


\section{HEEDER: ECSTATIC HYMNS}

through the encounter this hymn provides for you?

c. How does this hymn, offered in prayer, speak to where you are in your faith journey and relationship with God and others at this moment in time? 